\title{
VALUATION IN MULTIFINANCE COMPANIES ACQUISITION BY BANK MDR: A CASE STUDY
}

\author{
Jiwo Sukarno ${ }^{1} \&$ Tedy Fardiansyah ${ }^{2}$
}

\begin{abstract}
Bank MDR as one of leading banks in Indonesia, aims to capture 20 to $30 \%$ of revenue share in each of their businesses, including Consumer Finance. One crucial sub-segment in Consumer Finance Business is Automotive Loan, which currently dominated by Multifinance companies.

To increase the pace of becoming dominant in Automotive Loan, "inorganic initiatives" are required to supplement the organic efforts to grow the revenue shares of Bank MDR. In early 2009, Bank MDR engages in inorganic investment by acquiring a multifinance company, Tunas Finance. The main purpose of this study is to examine an alternative approach to value an acquisition of a multifinance company, as well as to observe whether the acquisition done by Bank MDR is creating value for its shareholders.

Valuation of an acquisition is not fundamentally different from valuation of any firm, however, valuing a multifinance company poses particular challenges. Given that Bank MDR has announced that it would pay 290 billion rupiahs for 51\% shares of Tunas Finance, this study, following Excess Return Model Valuation (Damodaran, 2002), shows results that acquirer shareholders still earn positive value from the acquisition.
\end{abstract}

Keywords: acquisition, valuation, multifinance companies.

${ }^{1}$ BINUS BUSINESS SCHOOL, BINUS UNIVERSITY, JWC Campus, Jl. Hang Lekir I No. 6, Kebayoran Baru, South Jakarta 12120, jiwo.sukarno@bankmandiri.co.id

2 Finance Investment in Risk Management Practitioner, tedyfrm@gmail.com 


\section{INTRODUCTION}

Eight months after the signing of Conditional Sales and Purchase Agreement (CSPA) between Bank MDR and shareholder of a multifinance company, PT Tunas Financindo Sarana ("Tunas Finance"), the acquisition process of the latter was finally completed. Ahsan Mariowedhana, CEO of Bank MDR, gave brief comments about the acquisition," We are all glad that the whole process has finalized. The strategic alliance between Bank MDR and Tunas Finance in consumer finance business, especially in automotive loan, should be started immediately. We expect that in three years, the synergy will be fruitful; where we become top three in the business, thus, support our mission to become Regional Champion Bank.” Founder of Tunas Group, who formerly owned 100\% of Tunas Finance could not agree more," With financing support from Bank MDR, combined with our expertise, it will not be long before the market sees a new leader in this business.”

Above paragraph is also the introduction of a case study about the latest acquisition done by Bank MDR. After acquiring a leading micro and small business loan bank in Bali, Bank MDR is making yet another headline as they acquire another firm to confirm their mission to become regional-class bank. Acquisition has become a choice for a firm to grow inorganically. Despite the drawback of acquiring another company in order to grow, it still becomes the preferred and fastest choice (Solovan, 2004). After all, it also proven to be profitable, not only for the target shareholder, but also the acquirer shareholder, if the valuation process -as part of the negotiation process - is done correctly (Bruner, 2003).

This study discusses the process of a multifinance company acquisition by Bank MDR, identifies reason, and analyzes the business valuation to justify the investment. It also enlightens how Bank MDR focuses on value creation of the synergy with its new subsidiary to achieve common goals.

\section{PROBLEM STATEMNT}

Valuation of an acquisition is not fundamentally different from valuation of any firm, however, valuing a multifinance company poses particular challenges. For instance, the fact that debt to multifinance companies is more like raw material, where they form it into financial products to be sold to the customer, taking a profit margin from the pricing strategy. Thus, the capital for multifinance companies is focused only on their equity capital. As regulated by authorities, banks and multifinance companies have to maintain their capital adequacy ratio at certain level, which focused in their equity. This fact, together with other characteristics of multifinance companies, pleads adjustments into its valuation method.

Another issue is, given that Bank MDR has announced that it will pay 290 billion rupiahs for $51 \%$ shares of Tunas Finance, pose a question whether the expected synergy value is still higher than the acquisition price paid by Bank MDR. In other words, the ultimate question is, how much, if any, is the value promised to the Bank's shareholders after the acquisition? 


\section{LITERATURE REVIEW}

Over the last 20 years, mergers and acquisitions (M\&A) activity has been one of the main methods for organizational growth. Firms acquired by or merged with other firms because of variety of reasons. The most prevalent in recent years being growth through external rather than internal means (Solovan, 2004). Many previous studies, using large samples of observations, show that that the acquisitions and mergers do pay on average (Bruner, 2005). The M\&As clearly pays for shareholder of target firms. Most studies indicate that the M\&As create net value for both the target and acquirer shareholders. Studies on bidders alone show that two-thirds of the studies conclude that value is at least conserved if not created.

Acquisition strategies need to be based on following motives (Damodaran, 2001):

1. Acquire undervalued firms: The acquirer gain the surplus difference between the value and the purchase price, which is at discount because the firm is undervalued.

2. Diversify to reduce risk: In a private firm, the owner may acquire other firms in other businesses to diversify risks.

3. Create operating or financial synergy. Synergy is a stated motive in many acquisitions. The existence of synergy implies that the combined firm will become more profitable or grow at a faster rate after the merger than will the firms operating separately.

In today market, the purchase price of an acquisition will nearly always be higher than the intrinsic value of the target company. An acquirer needs to be sure that there are enough cost savings and revenue generators -synergy value - to justify the premium so that the target company's shareholders don't get all the value that the deal creates (Eccles et al, 1999).

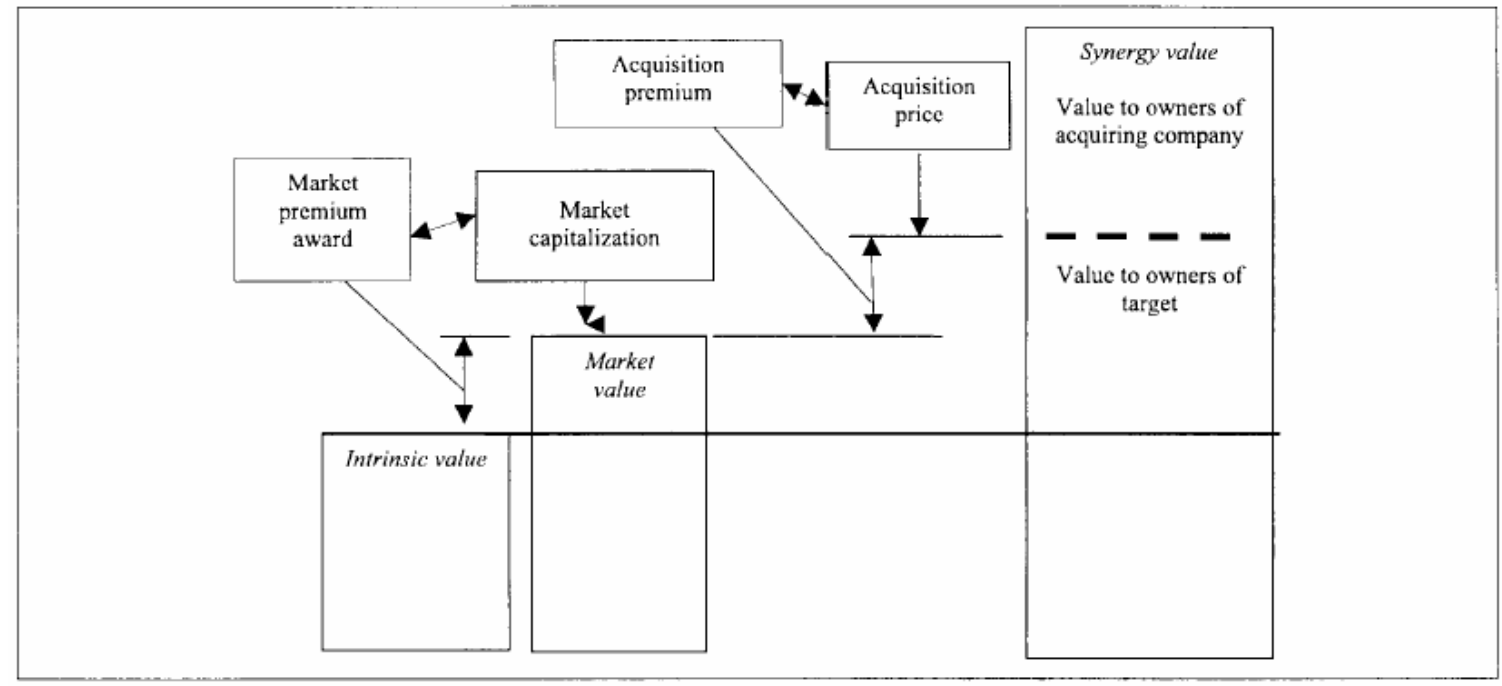

Figure 1. Value Sharing Among Shareholders of Acquiring and Target Company (Adapted from Eccles et al, 1999)

1. Intrinsic Value: The most basic value of the company, its intrinsic value, is based principally on the net present value of expected future cash flows completely independent of any acquisition. That assumes that the company continues under current management 
with whatever revenue growth and performance improvements have already been anticipated by the market.

2. Market Value: On the top of the intrinsic value, the market may add a premium to reflect the likelihood that an offer for the company will be made (or a higher offer will be tendered than one currently on the table). Market value -commonly called "current market capitalization" - is the same as the share price times the number of shares outstanding; it reflects the market participants' valuation of the company.

3. Acquisition Price: It's the price that a bidder anticipates having to pay to be accepted by the target shareholders. The difference between the intrinsic value and purchase price is value to the owners of target shareholders, also called Value Gap. In today's market, both the acquirer and the target company know that the purchase price will be higher than the intrinsic value -in other words, that the buyer will almost likely pay a premium, and that premium allocates some of the future benefits of the combination to the target shareholders. Absent a premium, most target shareholders would refuse to sell. The acquirer managers need to figure out just how large a value gap their company can bridge through synergies. The target, meanwhile, will second guess the acquirer, trying to calculate how high the price can be pushed. If there's more than one potential acquirer and the bidding gets competitive, that places even more upward pressure on the price.

4. Synergy Value: The net present value of the cash flows that will result from improvements made when the companies are combined. These are improvements above and beyond those the market already anticipates each company would make if the acquisition didn't occur, since those are already incorporated into the intrinsic value of each company. The gap between synergy value and acquisition price is the value that is earned by the shareholders of acquiring company.

Two keys to success in pricing an acquisition are to make sure that the assumptions used for calculating a target's synergy value are realistic. The second is to ensure that the acquirer pays no more than it should (Eccles, 1999).

Successful acquiring companies know how to calculate synergy value, and they know how to walk away from a deal that seems fabulous until someone runs the numbers. Damodaran (2005) argues that synergy can be valued by answering two fundamental questions:

1. In what form is the synergy expected to be? Will it be as a cost reduction? Will it be an increasing future growth or the length of the growth period? For the M\&A synergy, to have an effect on value, has to influence one of the four inputs into the valuation process higher cash flows from existing assets (cost savings and economies of scale), higher expected growth rates (market power, higher growth potential), a longer growth period (from increased competitive advantages), or a lower cost of capital (higher debt capacity).

2. When will the synergy start affecting cash flows? The synergies seldom show up instantaneously, but they are more likely to show up over time. Since the value of synergy is the present value of the cash flows created by it, the longer it takes for it to show up, the lesser its value.

The calculation for synergy value is based on the types of synergy itself (Damodaran, 2005):

1. Operating Synergy: Operating synergies are those synergies that allow firms to increase their operating income from existing assets, increase growth or both. Operating synergies could be categorized into four types. 
a. Economies of scale that may arise from the merger, allowing the combined firm to become more cost-efficient and profitable. It usually happens in mergers of firms in the same business (horizontal mergers)

b. Greater pricing power from reduced competition and higher market share, which should result in higher margins and operating income. This synergy is also more likely to show up in mergers of firms in the same business and should be more likely to yield benefits when there are relatively few firms in the business to begin with.

c. Combination of different functional strengths, as would be the case when a firm with strong marketing skills acquires a firm with a good product line. This can apply to wide variety of mergers since functional strengths can be transferable across businesses.

d. Higher growth in new or existing markets, arising from the combination of the two firms. This would be case, for instance, when a US consumer products firm acquires an emerging market firm, with an established distribution network and brand name recognition, and uses these strengths to increase sales of its products.

2. Financial Synergy: With financial synergies, the payoff can take the form of either higher cash flows or a lower cost of capital (discount rate) or both. Included in financial synergies are the following:

a. A combination of a firm with excess cash, or cash slack, (and limited project opportunities) and a firm with high-return projects (and limited cash) can yield a payoff in terms of higher value for the combined firm. The increase in value comes from the projects that can be taken with the excess cash that otherwise would not have been taken. This synergy is likely to show up most often when large firms acquire smaller firms, or when publicly traded firms acquire private businesses.

b. Debt capacity can increase, because when two firms combine, their earnings and cash flows may become more stable and predictable. This, in turn, allows them to borrow more than they could have as individual entities, which creates a tax benefit for the combined firm. This tax benefit usually manifests itself as a lower cost of capital for the combined firm.

c. Tax benefits can arise either from the acquisition taking advantage of tax laws to write up the target company's assets or from the use of net operating losses to shelter income. Thus, a profitable firm that acquires a money-losing firm may be able to use the net operating losses of the latter to reduce its tax burden. Alternatively, a firm that is able to increase its depreciation charges after an acquisition will save in taxes and increase its value.

d. Diversification is the most controversial source of financial synergy. In most publicly traded firms, investors can diversify at far lower cost and with more ease than the firm itself. For private businesses or closely held firms, there can be potential benefits from diversification.

Clearly, there is potential for synergy in many mergers. The more important issues relate to valuing this synergy and determining how much to pay for the synergy.

According to Damodaran (2002), Financial Service firms such as finance company, for example Multifinance companies in Indonesia, have some unique characteristics that can have implications for valuation:

1. Debt as Raw Material. It is argued that debt take different conotation for financial service firms. Rather than source of capital, debt to a Bank or Multifinance company is raw material. They molded it into financial products that can be sold at higher price and yield 
profit. Consequently, capital at financial services firms is more narrowly defined as only equity capital. Moreover, this definition of capital is reinforced by the regulatory authorities who evaluated the equity capital ratios of banks and other financial services firms.

2. The regulatory overlay. The regulation stated that financial service firms need to maintain capital ratios so that they do not expand beyond their means and put the depositors at risk, constraints their growth. These regulations, together with other restrictions, may change overtime and could have effects on future growth assumptions in the valuation.

3. Reinvestment at Financial Service Firms. It is also argued that measuring net capital expenditures and working capital in financial service firms could be problematic. Unlike manufacturing firms that reinvest a lot on plant, equipment or other fixed assets, multifinance companies invest so little in this kind of assets. Thus, multifinance companies show little in capex and low depreciation. With working capital (the difference between current assets and current liabilities) may not clearly defined in multifinance companies' financial statement, because the money is their commodities, it may have no relationship to reinvestment.

4. As a result in this difficulities in measuring reinvestment, the standard equations for measuring cash flow which requires net capex and changes in working capital can not be used. Moreover, estimating future growth becomes more difficult as there are no clear reinvestment rate.

Given the unique characteristics, Damodaran suggested that it makes far more sense to value equity directly at financial service firms (Free Cash Flow to Equity rather than Free Cash Flow to the Firm), and redefine reinvestment in Multifinance companies case to make it more meaningful.

The standard equations for Free Cash Flow to Equity (FCFE) is:

FCFE = Net Income - Net Capex - Change in noncash working capital - (Debt repaidNew Debt Issued)

As stated above that Capex and working capital cannot be measured for multifinance companies, so there are two choices:

1. Using dividends as cash flows, assuming that the multifinance companies pay out dividends over time, or

2. Using excess return models.

- In this model, the value of the firm can be written as the sum of capital invested currently in the firm and the present value of dollar excess returns that the firm expects to make in the future.

- As discussed earlier, in multifinance companies case, it makes sense to focus on equity only.

- The equity capital invested currently is measured as the book value of equity in the firm. Even though the book value depends very much on accounting method, in Multifinance companies case, the assets mostly are account receivables of automotive loan, which has no deviations with market value, unlike fixed assets such as plant or equipment, and has negligible depreciation.

- The excess returns can be formulated as: 
$=(\mathrm{ROE}-$ Cost of Equity $) *$ Equity Capital invested

$=\left(\mathrm{ROE}^{*}\right.$ Equity Capital invested $)-($ Cost of Equity* Equity Capital invested $)$

$=$ Net Income - Equity Cost

- Cost of Equity can be calculated using CAPM (Capital Asset Pricing Model). In CAPM, Beta of an investment is the risk that the investment adds to a market portfolio. The estimation of beta could be done using historical data on market prices, that is, only applicable for assets that have been traded (Damodaran, 2003). For a private company, beta could be estimated from the fundamental characteristics of the investment which can be localized in the business where the firm operates, a method called "bottom-up betas".

i. Identify the business where the firm operates

ii. Find other publicly traded firm in the business -the firm's comparables- and obtain their regression betas

iii. Unlever each beta by their debt to equity ratio

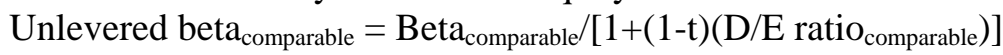

Where $t$ is tax rate for the firm.

iv. Estimate the unlevered beta for the firm being analyzed; taking a weighted average of the unlevered beta for each of comparables, using the proportion of operating income or revenues as weights. This weighted average is called the bottom-up unlevered beta

v. Estimate the current market values of debt and equity at the firm and use this debt to equity ratio to estimate a levered beta.

- Terminal Value on excess return model is calculated using following formula:

$=\left(\right.$ Net Income $_{\mathrm{n}}-$ Equity Cost $\left._{\mathrm{n}}\right) /$ (Cost of Equity - Expected Growth Rate)

Where $\mathrm{n}$ is the year beyond forecasted period.

- In measuring the growth of rate of investment, there is a method called Compound Annual Growth Rate (CAGR). Investopedia.com defines CAGR as the year-over-year growth rate of an investment over a specified period of time. It is calculated by taking $n$ th root of total percentage growth rate, where $n$ is the number of years in the period being considered.

CAGR $=\left((\text { ending value/beginning value })^{\wedge}(1 / n)\right)-1$

CAGR isn't the actual return in reality. It's an imaginary number that describes the rate at which an investment would have grown if it grew at a steady rate, as a way to smooth out the returns.

Common errors in valuing acquisitions are:

1. Subsidizing Target Firm Stockholders: Acquiring firm should not render unto target firm stockholders premium for items or strengths that these stockholders had no role in creating. For example: Using acquiring firm's cost of debt in computing cost of capital of target firm when the acquiring firm has better credit rating. The lower cost of capital will result in higher value for target firm, while the stockholder of target firm has no involvement in maintaining acquirer's good credit rating.

2. Using wrong discount rate: Synergy usually generates incremental cash flows over future periods, and valuing these cash flows requires a discount rate. Using wrong discount rate on synergy cash flows will result in synergy being wrongly valued. The general principle that governs the estimation of discount rates, which is that they should reflect the nondiversifiable risk in the cash flows, and it continuous to hold when it comes to cash flows 
from synergies. For example: if after the acquisition, it requires the combined firm to achieve the incremental cash flows (horizontal mergers), then the discount rate used should be the combined firm's cost of capital/equity.

3. Mixed control and synergy valuation: While synergy is used as a reason for many mergers, the other widely used reason is control. The value of control derives from changing the way a company is run and will be higher at poorly managed or run firms. In other hand, synergy requires the two entities to work together. Mixing the two will confuse the value of control and synergy. In order not to confuse the two, the value of control should be estimated first by valuing the target firm twice, once on a status quo basis and once with the changes/restructuring that is intended in how the company is run. After that, the valuation of synergy should follow the method discussed earlier in this chapter.

\section{METHODOLOGY}

This study is developed using a case study method. The ultimate goal is to learn from the case and be able to take correct actions should the same occurrence happens in the future.

This study gathers and organizes relevant data from trusted primary source and analyzes it using Damodaran's valuation theoretical framework.

The data collected from financial statement of Tunas Finance from 2003-2007 and their unaudited Financial Statement up until June 2008 is:

1. Net Income and Book Value of Equity of that period

2. ROE of each year, by dividing Net Income with the equity. The calculation of ROE can be crosschecked with the value from Tunas Finance Financial Performance 20032008.

Following methods are used in this valuation using excess return model.

1. Calculating cost of equity using CAPM

2. Projecting the future net income (2009-2011)

3. Projecting the future ROE (2009-2011)

4. Calculating terminal value using stable growth model

\section{CASE ANALYSIS}

The following steps are conducted to calculate the valuation of the acquisition:

1. Calculating Cost of Equity using CAPM:

a. Tunas Finance is a private company, although its current parent company, Tunas Group (TURI) is publicly traded in Indonesian Stock Exchange (IDX). Thus, Tunas Finance's beta is calculated using bottom up betas method, as explained in the literature review, as follows:

i. This method estimates a private company beta started with unlevering comparable public firms with their D/E Ratios.

ii. The comparables are selected from listed multifinance companies in Indonesian Stock Exchange. 
iii. The comparables selected are the firm with assets of more than Rp 1 Trillion. They are: Adira Multifinance companies (ADMF), BFI Finance (BFIN), Clipan Finance (CFIN), Buana Finance (BBLD), Mandala Finance (MFIN) and Wahana Ottomitra (WOMF). Their beta is calculated from their historical market prices against Jakarta equity index. After their betas are gathered, it is unlevered using each $\mathrm{D} / \mathrm{E}$ ratio.

Table 1. Comparison to Competitors (as of Q2 2008)

\begin{tabular}{|l|l|l|l|}
\hline \multicolumn{1}{|c|}{ Firms } & \multicolumn{1}{|c|}{ Beta } & $\begin{array}{c}\text { Debt-to- } \\
\text { Equity }\end{array}$ & $\begin{array}{c}\text { Operating } \\
\text { Profit (Rp Bill) }\end{array}$ \\
\hline Adira Finance (ADMF) & 0.38 & 1.12 & 603 \\
\hline BFI Finance (BFIN) & 0.15 & 1.56 & 167 \\
\hline Clipan Finance (CFIN) & 0.69 & 0.56 & 92 \\
\hline Mandala Finance (MFIN) & 1.11 & 4.53 & 89 \\
\hline Buana Finance (BBLD) & 0.34 & 0.98 & 46 \\
\hline Wahana Ottomitra (WOMF) & 1.02 & 9.99 & 31 \\
\hline
\end{tabular}

Source: $\underline{w w w . i d x . c o . i d}$ and writer's estimates

iv. The unlevered comparable firms' betas are weighted using Q2 2008 operating profit, to get Tunas Finance's unlevered beta. Unlevered beta for Tunas Finance is 0.21 .

v. Beta for Tunas Finance is gathered from levering the unlevered beta with Tunas Finance's D/E Ratio, which is 6.32. Levered beta of Tunas Finance is 1.19 .

b. Risk free rate is based on Indonesian Government 5-year Bond yield valued around Q2 2008, which is $11.24 \%$ (Mansec, 2008)

c. Market Premium is calculated by subtracting Risk Free Rate from Jakarta Composite Index return measured from year 1997 to Q2 2008, which is $19.70 \%$.

d. The calculation results cost of equity of $=11.24 \%+(1.19 *(19.70 \%-11.24 \%)=$ $21.29 \%$.

2. The cost of equity gathered in step number 1 will be unchanged over 2009-2011

3. Projected Net Income 2009-2011 assumed the same as compounded annual growth rate (CAGR) for the past 5 years (2003-2008) which is $20.2 \%$, with no business model change. This assumption is made as multifinance companies business in the future will likely match the obstacles left by global financial crisis, so it must mirror the growth rate from their past performance. Considering that the past growth rate is unstable as it was hit by the increase in oil price back in 2005, the author decided to use CAGR to capture the firm's ability in terms of growing their net income annually in a periodic where unstable condition is likely to happen again.

4. Past performance's ROE is averaged at $22.60 \%$, so in this status quo valuation, it is assumed that it will not change for 2009-2011.

5. Terminal Value at year 2012 calculated using stable growth model with stable growth of 5\% perpetually, a little below the expected GDP of 5.1-5.2\% (Mansec, 2008). 
From the calculations, the cost of equity is $21.29 \%$ and total equity value is Rp 553.4 Billions. Bank MDR spent Rp 290 Billions for 51\% of Tunas Finance's stake, where it should be priced at 51\%* Rp 553.4 Billions = Rp 282,2 Billions for it’s intrinsic value.

It can be concluded that the value transferred to target firm shareholder is Rp 290 Billions- Rp 282.3 Billions = Rp 7,7 Billions.

For Bank MDR to control Tunas Finance, the latter must be valued at its maximum potential, as discussed in literature review. Thus, there is a need to change its business model.

From the comparison with its competitors, the target firm has a considerably high Debt-to-equity ratio, even though as regulated by Ministry of Finance (No 84/PMK.12/2006) that gearing ratio is limited at 10 times. The difference with the competitors is mainly because the competitors are engaging in a joint finance scheme to their customer.

Joint Financing is when a third party - usually a bank- agrees to finance customer together with the Multifinance companies, with each holding credit risk proportional to the amount financed. Thus, the capital for consumer financing arises from bank loan no longer exist, shown only in off-the book records.

The target firm, however, not yet involve in any joint financing scheme with any commercial bank, as this transaction requires the system used in both parties to be mirroring. Adira and Clipan however, have done such a business model with their parent company of Bank Danamon and Bank Panin respectively.

Thus, for control value valuation, it is assumed that the net income projection is similar to the status quo valuation. However, Tunas Finance will start to ask for joint financing scheme with their bankers partners.

Further assumptions for this valuation would be:

1. DER level will declining to represent the joint financing scheme, but it takes about three years before it reached DER around 1 as to keep their capital structure healthy. Three years is the average credit tenor of its customers, as is their loan term to their creditor. DER of 2009, 2010, and 2011 will be using supported data from Tunas Finance, which are 4.51, 2.29, and 1.27 respectively. The decreasing level of DER must also be done in a way that it will not hurt the relationship with existing creditors (commercial banks).

2. The declining DER will result in much lower Beta, which causes their cost of equity also fall.

3. Projected Net Income $2009-2011$ is $20.2 \%$, as discussed in status quo valuation section

4. ROE for 2009-2011 is also using the average of past performance result

5. Terminal Value at year 2012 calculated using stable growth model with stable growth of $5 \%$ perpetually

As a result, the accepted acquisition price of Tunas Finance as a whole is Rp 1,619.1 Billions. Bank MDR spent Rp 290 Billions for 51\% of Tunas Finance's stake, where it should be priced at 51\%* Rp 1,619.1 Billions = Rp 825.7 Billions. It can be concluded that the purchase price was in favor for Bank MDR. 
Considering the Prospective Synergy between the new owners, Bank MDR, as discussed earlier in this chapter, the cash flow will be incremented as to accommodate the revenue enhancement.

Bank MDR targeted the net income of 2009-2011 in line with their mission to achieve 20-30\% market share in Automotive Loan by 2010, by engaging Joint Financing scheme with Tunas Finance as early as 2009.

Assumptions for this valuation:

1. Declining DER to accommodate joint financing scheme between Bank MDR and Tunas Finance as its new subsidiary, thus also cost of equity

2. Projected Net Income 2009-2011 is forecasted accomodating negative year on year change in 2009, as a result of consolidation period required to be a newly subsidiary of Bank MDR

3. ROE of 2009-2011 can be configured from the forecast

4. Terminal Value at year 2012 calculated using stable growth model with stable growth of $5 \%$ perpetually.

As a result the synergy value calculated is Rp 1,907.9 Billions, which means that the value to Bank MDR's shareholders is Rp 1,907.9 Billions *51\% substracted by Rp 290 Billions $=$ Rp 683,1 Billions. below:

Summary of synergy valuation of Bank MDR's acquisition of Tunas Finance is shown

\begin{tabular}{|l|c|c|}
\hline Valuation & \multicolumn{1}{|c|}{ IDR-millions } \\
\hline Purchase Price & & $290,000.00$ \\
\hline Value to Target Shareholder & & $7,765.14$ \\
\hline Value to Acquirer Shareholder & & $683,071.31$ \\
\hline
\end{tabular}

\section{CONCLUSION}

The conclusions from this study are:

1. Multifinance companies, given their unique characteristics, can be valued using excess return model, as suggested by Professor Aswath Damodaran of New York University.

2. Value to the target shareholder is around Rp 7 Billions in excess to the purchase price; however, this value is justified considering the projection of synergy value transferred to acquirer shareholder, which is around Rp 683 Billions.

3. The synergy expected between the two in this case, is operating synergy, by targeting an enhancement to the projected revenue, as well as financial synergy under the terms of maximizing "cash slack" of Bank MDR in joint financing scheme with their new subsidiary, Tunas Finance.

\section{REFERENCES}

Adityaswara, M. (2009). Indonesia Update. PT Bank Mandiri (Persero) Tbk Office of Chief Economist, Jakarta. 
Alison, L.M. (1984). The Accountant Role In Acquisition Analysis, Journal of Management Accounting.

Anderson, C.M., (1987). 1+1=3. Journal of Management Accounting.

Bruner, R., (2004). Applied Mergers and Acquisitions. New Jersey: Wiley Finance.

Chanmugam et al., (2005). Ensuring Value Capture in M\&A. Journal of Business Strategy.

Damodaran, A. (2002). Investment Valuation $2^{\text {nd }}$ Edition. New Jersey: Wiley Finance.

Damodaran, A. (2005). The Value of Synergy. Stern School of Business, available at http://www.damodaran.com.

Eccles et al., (1999). Are You Paying Too Much For That Acquisition?. Harvard Business Review.

Solovan, K., (2004). M\&A: The Strategic Role of Management Accountant, CPA Journal. 